\title{
Design, Fabrication and Performance Test of Ethanol Extractor from Cassava
}

\author{
K. C. Ugwu and A. Omoruyi
}

\begin{abstract}
The ethanol extractor was design, fabricated and its performance was evaluated. It comprises of two plastic containers (fermentation and separating tanks) each of which is 41.2 litters in capacity and a steam boiler of $\mathbf{1 0 . 6}$ liters in capacity which was mounted on an electric heater and the temperature was controlled by a thermostat. Aluminum pipe was used to connect the steam boiler by the top side in which gaseous ethanol flows to the water jacket of $\mathbf{1 5 . 3}$ liters in capacity to condense the ethanol to liquid which is collected at the bottom side of the water jacket. Thermometer was mounted on the steam boiler to read the temperature of the mixture inside the steam boiler. Continuous flow of water is ensured in the water jacket to enhance the rate of condensation. The performance test was carried out using four different feed rates of cassava starch at two different durations of extraction which include $500 \mathrm{~g}, 1000 \mathrm{~g}, 1500 \mathrm{~g}$ and $2000 \mathrm{~g}$ at 180 minutes and 200minutes. Each one was replicated five times. The results showed that the quantity of alcoholic extracted depends on quantity of starch used. The high the quantity of cassava starch will lead to high durations of extraction that produced high volume of ethanol. The Analysis of Variance (ANOVA) for the effect of feed rates and time on the efficiency of the machine confirms that these factors are important parameters that significantly affect the performance and the volume of ethanol extracted by the machine.
\end{abstract}

Index Terms - Design, Fabrication, Performance test, cassava, ethanol extractor.

\section{INTRODUCTION}

The term alcohol comes from the Arab word "Alkol" denoting essence of spirit. They constitute a general class of organic compounds having characteristic property and reactions [3].

Ethanol, chemically known as ethyl alcohol, is the second member of the aliphatic alcohol series; it is a clear, volatile, flammable, colorless liquid with an agreeable odor. It can be detected in traces of Free State or in form of its esters as it is .produced in plant and animals by decomposition of complex organic compounds.

Ethanol can be produce from the fermentation of sugar and it is the alcoholic beverages. Local gin, popularly known as illicit gin is produced from palm wine. Fresh

Manuscript published August 31, 2016

K.C. ugwu is with the Department of Agricultural and Bioresource Engineering, Enugu State University of Science and Technology, Enugu, Nigeria, chikwadok@yahoo.com.

A Omoruyi is with the Department Agricultural Engineering, Edo State College of Agriculture, Iguoriaku, Edo, Nigeria.

tonruyi@yahoo.com palm wine, which contains sugar yeast, can be fermented to produce ethanol [5].

In Nigeria, local production of ethanol from maize, guinea corn, millet, other starchy substrates, and cellulose is as old as the country itself [6].

The use of cassava as a raw material for the production of ethanol although not popular due to other intensified domestic use of cassava for the production of garri, fufu, cassava flour with high yield and less cost of production compare to the production of ethanol. Industrially, cassava can be used for the production of starch, dextrin, glues, binders, stabilizer, fillers, dusting agents, and single cell protein [5].

Synthetic ethanol has exactly the same properties as ethanol produce by fermentation [12]. Apart from food and pharmaceutical uses, ethanol is founding itself an alternative use for bio fuel in most of the developed world. The reasons for using ethanol for bio fuel are: it is not poisonous, it does not contribute to the greenhouse effect problem $\left(\mathrm{CO}_{2}\right)$ addition to the atmosphere causing global warming), It does not cause air pollution or environmental hazard, It has high octane rate than petrol as fuel. Ethanol is octane booster and anti-knocking agent and it is an excellent raw material for synthetic chemicals, Ethanol provides job and economic development in rural areas, ethanol reduces country's dependence on petroleum and it is a source of non-revenue for any producing country and ethanol is capable of reducing the adverse foreign trade balance [6].

Cassava also known as manioc or tapioca root is a dicotyledous plant, 1-3 meters height when fully grown. It belongs to the family of Euphurbiaceae and the genus manihot esculenta represent a whole complex of cultivars of cassava that taxonomist have from time to time tried to separate into district species with little success [13].

Cassava (Manihot ultissima), which is a native South America and Southern and western Mexico, was one of the first crops to be domesticated and there is evidence that it was grown in Peru some 4,000 years ago and in Mexico some 2,000 years ago. The plant, which is a root crop, is a short-lived shrub which is grown almost anywhere in the area between latitude $30^{\circ} \mathrm{S}$, and is potentially one of the most efficient crops in terms of carbohydrates production. It is adapted to temperature ranging from 18 to $25^{\circ} \mathrm{C}$ and to rainfall of 50 to $5,000 \mathrm{~mm}$ annually, and to poor soils with $\mathrm{pH}$ ranging from 4 to 9 [1].

Cassava plant probably originated in Brazil, which is regarded as the leading world producer followed closely by Indonesia. Since 1990, Nigeria has surpassed Brazil as the world's leading producer of cassava with an estimated annual production of 26 million tonnes from an estimated area of 1.7 million hectares of land. Other major producers 
of cassava are Zaire, Thailand, China, Indonesia, Malaysia, Malawi, Togo and Tanzania [4].

A mature cassava root depending on the cultivar, field management and at maturity may range in length from 15 to $100 \mathrm{~cm}$ and weigh 0.5 to $2.5 \mathrm{~kg}$, and the food quality of the roots, particularly the starch content increases with time up to an optimal period of 12 to 15 months after planting.

Table1: Energy Content of Some Fuel Compare with Ethanol

\begin{tabular}{|c|c|c|c|}
\hline Fuel Type & $\mathrm{MJ} / \mathrm{L}$ & $\mathrm{MJ} / \mathrm{Kg}$ & $\begin{array}{l}\text { Research } \\
\text { Octane } \\
\text { number }\end{array}$ \\
\hline Dry Wood (20\%) & & 19.5 & \\
\hline Methanol & 17.9 & 19.9 & 123 \\
\hline Ethanol & 23.3 & 31.1 & 129 \\
\hline $\begin{array}{l}\text { E85\% (ethanol, } 15 \% \\
\text { gasoline) }\end{array}$ & 25.2 & 33.2 & 105 \\
\hline Liquefied natural gas & 25.3 & 55 & \\
\hline $\begin{array}{l}\text { Auto (LPG) ( } 60 \% \text { propane } \\
+40 \% \text { butane) }\end{array}$ & 26.8 & 50 & \\
\hline $\begin{array}{l}\text { Gasohol }(90 \% \text { gasohol } \\
+10 \% \text { thanol })\end{array}$ & 33.2 & 47.1 & 93194 \\
\hline Regular gasoline & 34.8 & 44.4 & Min 91 \\
\hline Premium Gasoline & & & $\operatorname{Max} 95$ \\
\hline Diesel & 38.6 & 45.4 & 25 \\
\hline Charcoal, extruded & 50 & 23 & \\
\hline
\end{tabular}

Source: [14]

Cassava may be harvested in 10-14months, but at least, it requires 8 months of warm weather to produce crop [1].

Alcoholic beverages can be made from the roots, young tender leaves can be used as a potherb, containing high level of protein (8-10\% F.W.) prepared in a similar manner as spinach, roots are processed in several different ways. They may be first fermented in water, should be taken to eliminate toxic compounds during the cooking process. One clone with variegated leaves is planted and its cassava is further dried over a fire to make a meal or fermented and cooked. The meal can then be dehydrated with water or added to soups or stews [7].

The fermentation of sugar into ethanol is one of earliest organic reactions employed by humanity. The intoxicating effects of the ethanol consumption have been known since ancient times. In modern times, ethanol intended for industrial use is also produced from by-products of petroleum refining. Ethanol has wide spread use as a solvent of substances intended for human contact or consumption, including scents, flavourings, colourings, and medicines. In chemistry, it is both an essential solvent and a feed stock for the synthesis of other products. It has a long history as a fuel of heat and light and also as a fuel for internal combustion engine [10].

Ethanol has a smaller heat value but higher octane rate than gasoline, which enable higher engine efficiency with large compression ratio. It present, it is more advantageous in terms of energy rate and cost to get it from sugar crop, especially from sugar cane in tropical countries. New sugar crops are also being searched for. In the temperate region, ethanol is usually obtained from the fermentation of starchy crops like corn, cassava and potato. Reduction in the cost of fermentation process including the pretreatment, are ongoing. New technologies are being developed to get it from cellulosic biomass with a simultaneous saccharification and fermentation method, which will enable us to utilize all parts, except lignin, of the grassy plants. Ethanol is use for spark-ignition engine either in the form of a $20 \%-23 \%$ mixture with gasoline or in its pure from. The latter requires a newly designed engine with a higher compression ratio and hence can achieve higher efficiency [9].

The largest single use of ethanol is a motor fuel in ethanol industries which exist is brazil (gasoline sold in brazil contain at least $25 \%$ ethanol and anhydrous ethanol is also used as fuel in more than $99 \%$ of new cars sold in the country ). The Brazilian production of ethanol is praised for the high carbon sequestration capacities of the sugarcane plantations, thus making it a real option to combat climate change [14].

Ethanol, which is the same chemical as the alcohol beverages, can reach $96 \%$ purity by volume through distillation, and is as clear as water. This is enough for straight ethanol combustion. For blending with gasoline, purities of 99.5 to $99.9 \%$ are required, depending on temperature to avoid separation. Ethanol is flammable and pure ethanol burns more clearly than many other fuels. When fully combusted, its combustion products are only carbon dioxide and water which are also the by-products of regular cellulose waste decomposition. For this reason, it is favored for environmentally conscious transport schemes and has been used for public buses [6].

Fermentation is the slow decomposition of complex organic compound into simpler compounds through the agency of enzyme. It is the process of deriving energy from oxidation of organic compounds, such as carbohydrates, using an endogenous electron acceptor, which is usually an organic compound. Sugars are the most common substrate of fermentation, and typical examples of fermentation products are ethanol, lactic acid, and hydrogen. However, more exotic products are ethanol, lactic acid, and hydrogen. However, more exotic compounds can be produced by fermentation, such as butyric acid and acetone. Yeast carries out fermentation in the production of ethanol in beers, wines and other alcoholic drinks, along with production of large quantities of carbon dioxide [11][8].

Traditionally, in the United States industrial alcohol prepared by fermentation has black strap molasses which contain up to 50\% sugar and can be easily fermented. The starting mash is prepared by diluting the molasses with water to bring the sugar content down to about $15 \%$ (weight). The mash is slightly acidified, after which invertase (enzyme to convert sucrose) and zymase (enzymes to convert glucose to fructose) are added. The products are ethanol and carbon dioxide, yeast activity is sustained by the addition of nutrients with careful control of temperature and acidity. The fermentation process can be completed in about two days. The resulting mash usually contains about $12 \%$ ethanol which is recovered from the beer by distillation. Yeast contains enzymes invertase zymase and one of the keys to the fermentation process is that invertase catalyses the hydrolysis of sucrose in mash invert sugar. Yeast itself is not consumed or changed during fermentation and merely functions as a producing agent for the enzymes that catalyse the conversion $\mathrm{C}_{12} \mathrm{H}_{22} \mathrm{O}_{11}$ invertase, $\mathrm{C}_{6} \mathrm{H}_{12} \mathrm{O}_{6}+\mathrm{C}_{6} \mathrm{H}_{12} \mathrm{O}_{6}$ invert sugars are subsequently converted into parts ethyl alcohol and carbon dioxide by action of zymases $\mathrm{C}_{6} \mathrm{H}_{12} \mathrm{O}_{6}+\mathrm{H}_{2} \mathrm{O}$ zymase $2 \mathrm{CH}_{3} \mathrm{CH}_{2} \mathrm{OH}+2 \mathrm{CO}_{2}$. [5].

Distillation involves the separation, selection, and concentration of the alcoholic products of yeast 
fermentation from the fermented grain mash, sometimes referred to as "fermented worth" or "distiller's beer". In addition to the alcohol and desirable secondary products (congeners), the fermented mash contains solid grain particles, yeast cells, water soluble proteins, some mineral salts, lactic acid, and traces of glycerol and succinic acid. Distillation can be done in batch or continuous system [2]. This first type of plant will produce a strong alcohol from cassava, but this will have an odour as the distilling process is very crude. The plant would bring in fresh cassava, wash and peel, grate, cook in a jet cooker, ferment, distill, and bottle. In addition a stream boiler, generating set, effluent treatment plant and electrical system are required. The actual amount of cassava needed is dependent upon the starch content, but as a guide, cassava at $30 \%$ starch content will produce approximately 280 liters of alcohol /tonne. Cassava with only $20 \%$ starch will produce approximately 180 litres/tonne. This plant operates on a batch basis and can process approximately 4-6 batches/24hours producing 500 liters of alcohol/batch. The plant will need good electricity supply (around 50kva). The stream requirements are around $1500 \mathrm{~kg} \mid$ hour [6].

Production of ethanol for bio-fuel will reduce the demand for petroleum as a source of energy for powering engine and also reduce environmental pollution of petrol through the emission of carbon dioxide $\left(\mathrm{CO}_{2}\right)$ from the combustion when mixing the ethanol and petrol in correct blend ratio for powering engine. The specific objective of the work is to design, fabricate and to carry out the performance test of the extractor.

\section{MATERIALS AND METHODS}

An ethanol extractor from cassava, that is efficient and economically viable was designed and fabricated with readily available and cheap materials (suitable engineering materials that could give optimum performance in service). Materials for fabricating the extractor were chosen on the basis of their availability, suitability, economic consideration, viability in service etc. The components parts of the machine were designed fabricated and tested. The parts and their quantity are given in the part list below.

\section{A. Principle of Operation}

The machine was designed to extract ethanol from the mixture of water and ethanol. This was achieved by peeling the fresh cassava roots, wash, grate and sieved. The starch collected was then gelatinized using homogenizer at a temperature of $70^{\circ} \mathrm{C}$. After which tetraoxosulphate IV acid was added and it was placed back to the homogenizer for hydrolysis to take place. The mixture was then neutralized with sodium hydroxide. Then it was allowed to cool and then yeast was added for the conversion of starch to simple sugar which was allowed for fermentation for three days at suitable temperature. The fermentation took place in the fermentation tank (Plastic container 1) which the mixture was then released to the separating tank (Plastic container 2) which container sieve to trap any residue. The filtrate through the gauge valve of the separator was opened and the filtrate flowed into the stream boiler through pipe connection where heat was supplied by the electric heater for distillation of the ethanol. The gaseous ethanol vapour flowed through the galvanized pipe at the top side of the steam boiler into the water jacket which contained water for the gaseous ethanol to condense and the liquid ethanol was collected. The heated water in the water jacket was discharge through the tap at the bottom side of the water jacket and it was refilled with fresh water

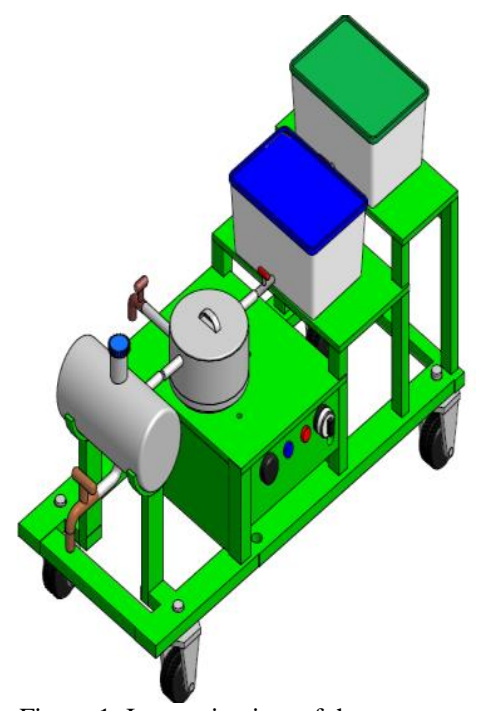

Figure 1. Isometric view of the extractor

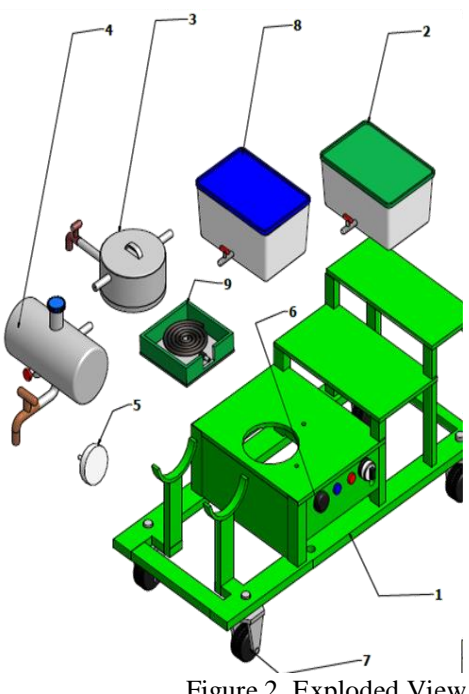

\begin{tabular}{|l|l|l|}
\hline Item & Qty & Part Name \\
\hline 1 & 1 & Frame \\
\hline 2 & 1 & $\begin{array}{l}\text { Fermentation } \\
\text { Tank }\end{array}$ \\
\hline 3 & 1 & $\begin{array}{l}\text { Separating } \\
\text { Tank }\end{array}$ \\
\hline 4 & 1 & $\begin{array}{l}\text { Thermomete } \\
\text { r }\end{array}$ \\
\hline 5 & 1 & Steam boiler \\
\hline 6 & 1 & Water jacket \\
\hline 7 & 1 & $\begin{array}{l}\text { Heating } \\
\text { Element }\end{array}$ \\
\hline 8 & 1 & Thermostat \\
\hline 9 & 1 & Switch \\
\hline
\end{tabular}

Figure 2. Exploded View of the extractor

\section{B. Testing the Extractor}

The extractor was tested using four different quantity of cassava starch at two different durations of extraction. Testing the machine was targeted at evaluating the efficiency of the machine using these feed rates and time. The results obtained were analyzed using analysis of variance (ANOVA). The steps used for testing of the extractor include:

1. The cassava starch was collected and then place into a glass beaker and then gelatinized using Homogenizer at a temperature of $70^{\circ} \mathrm{C}$ for one hour.

2. Tetraoxosulphate (vi) acid was introduced into the sample and allowed to stay for 48 hours for breaking of bonds between the molecules of the starch.

3. The hydrolyzed starch was allowed to cool for some hours and the neutralized with $\mathrm{NaOH}$ solution and yeast was also introduced. 
4. After stirring, the starch was introduced into the fermentation tank and it was allowed for three days for proper conversion of complex sugar into simple sugar.

5. The filtration was taken place at separation tank and through the separation tap the fermented starch entered the distillation Pot, after which the tap between the pot and separating tank was closed.

6. The fuse of the extractor was then connected to power and the regulator of the thermostat was set at $78^{\circ} \mathrm{C}$ to avoid the temperature exceeding the boiling point of ethanol.

7. Cooled water was introduced into the cylinder of the water jacket for condensation of gaseous ethanol into liquid in the cylinder and then a plastic bottle was placed at the outlet tap of the water jacket for collection of ethanol as it comes out.

8. After distillation, the outlet tap of the distillation pot was opened for the discharge of the remaining slurry.

\section{RESULTS AND DISCUSSION}

The performance test of the extractor was performed using four different quantity of starch from cassava at two different durations to know the volume of ethanol recovered. It was observed in table 2, that the average volume of alcoholic recovered at 180 minutes was equal to that of 200 minutes. This means that time does not influence the volume of alcoholic extracted at $500 \mathrm{~g}$ feed rate.

\begin{tabular}{|c|c|c|c|c|c|c|c|}
\hline $\mathrm{S} / \mathrm{N}$ & $\begin{array}{l}\text { Mass } \\
\text { of } \\
\text { Starch } \\
(\mathrm{g})\end{array}$ & $\begin{array}{l}\text { Volu } \\
\text { me of } \\
\mathrm{H}_{2} \mathrm{SO}_{4} \\
(\mathrm{ml})\end{array}$ & $\begin{array}{l}\text { Mass } \\
\text { of } \\
\mathrm{NaOH} \\
(\mathrm{g})\end{array}$ & $\begin{array}{l}\text { Mass } \\
\text { of } \\
\text { Yeas } \\
t(g)\end{array}$ & $\begin{array}{l}\text { Volu } \\
\text { me of } \\
\mathrm{H}_{2} \mathrm{O} \\
\text { used } \\
(\mathrm{ml})\end{array}$ & $\begin{array}{l}\mathrm{Ti} \\
\mathrm{me} \\
(\mathrm{mi} \\
\mathrm{n})\end{array}$ & $\begin{array}{l}\text { Volume } \\
\text { of } \\
\text { Ethanol } \\
\text { Obtained } \\
\text { (litre) }\end{array}$ \\
\hline 1 & 500 & 13.59 & 20 & 105 & 500 & 180 & 0.18 \\
\hline 2 & 500 & 13.59 & 20 & 105 & 500 & 180 & 0.21 \\
\hline 3 & 500 & 13.59 & 20 & 105 & 500 & 180 & 0.20 \\
\hline 4 & 500 & 13.59 & 20 & 105 & 500 & 180 & 0.21 \\
\hline 5 & 500 & 13.59 & 20 & 105 & 500 & 180 & 0.20 \\
\hline Total & & & & & & & 1.00 \\
\hline Average & & & & & & & 0.20 \\
\hline 6 & 500 & 13.59 & 20 & 105 & 500 & 200 & 0.19 \\
\hline 7 & 500 & 13.59 & 20 & 105 & 500 & 200 & 0.22 \\
\hline 8 & 500 & 13.59 & 20 & 105 & 500 & 200 & 0.20 \\
\hline 9 & 500 & 13.59 & 20 & 105 & 500 & 200 & 0.21 \\
\hline 10 & 500 & 13.59 & 20 & 105 & 500 & 200 & 0.18 \\
\hline Total & & & & & & & 1.00 \\
\hline Average & & & & & & & 0.20 \\
\hline
\end{tabular}

The results obtained in table 3 using $1000 \mathrm{~g}$ feed rate of starch showed that the average volume of alcoholic gotten at 200 minutes (0.43litres) was greater than the 180 minutes (0.39litres). This shows that as the time of extraction increases, then the volume of alcoholic recovered also increases.

\begin{tabular}{|c|c|c|c|c|c|c|c|}
\hline $\mathrm{S} / \mathrm{N}$ & $\begin{array}{l}\text { Mass } \\
\text { of } \\
\text { Starch } \\
(\mathrm{g})\end{array}$ & $\begin{array}{l}\text { Volu } \\
\text { me of } \\
\mathrm{H}_{2} \mathrm{SO}_{4} \\
(\mathrm{ml})\end{array}$ & $\begin{array}{l}\text { Mass } \\
\text { of } \\
\mathrm{NaOH} \\
(\mathrm{g})\end{array}$ & $\begin{array}{l}\text { Mass } \\
\text { of } \\
\text { Yeast } \\
\text { (g) }\end{array}$ & $\begin{array}{l}\text { Volu } \\
\text { me of } \\
\mathrm{H}_{2} \mathrm{O} \\
\text { used } \\
\text { (ml) }\end{array}$ & $\begin{array}{l}\mathrm{Ti} \\
\mathrm{me} \\
(\mathrm{mi} \\
\mathrm{n})\end{array}$ & $\begin{array}{l}\text { Volume } \\
\text { of } \\
\text { Ethanol } \\
\text { Obtained } \\
\text { (liter) }\end{array}$ \\
\hline 1 & 1000 & 27.17 & 40 & 210 & 1000 & 180 & 0.34 \\
\hline 2 & 1000 & 27.17 & 40 & 210 & 1000 & 180 & 0.40 \\
\hline 3 & 1000 & 27.17 & 40 & 210 & 1000 & 180 & 0.39 \\
\hline 4 & 1000 & 27.17 & 40 & 210 & 1000 & 180 & 0.41 \\
\hline 5 & 1000 & 27.17 & 40 & 210 & 1000 & 180 & 0.39 \\
\hline Total & & & & & & & 1.97 \\
\hline Average & & & & & & & 0.39 \\
\hline 6 & 1000 & 27.17 & 40 & 210 & 1000 & 200 & 0.45 \\
\hline 7 & 1000 & 27.17 & 40 & 210 & 1000 & 200 & 0.43 \\
\hline 8 & 1000 & 27.17 & 40 & 210 & 1000 & 200 & 0.42 \\
\hline 9 & 1000 & 27.17 & 40 & 210 & 1000 & 200 & 0.40 \\
\hline 10 & 1000 & 27.17 & 40 & 210 & 1000 & 200 & 0.43 \\
\hline Total & & & & & & & 2.13 \\
\hline Average & & & & & & & 0.43 \\
\hline
\end{tabular}

The table 4 results also showed high average volume of alcoholic at 200 minutes (0.61litres) to 180 minutes (0.59litres) during the extraction. It means that the higher the time, the higher the volume of alcoholic extracted.

\begin{tabular}{|c|c|c|c|c|c|c|c|}
\hline $\mathrm{S} / \mathrm{N}$ & $\begin{array}{l}\text { Mass } \\
\text { of } \\
\text { Starch } \\
(\mathrm{g})\end{array}$ & $\begin{array}{l}\text { Volu } \\
\text { me of } \\
\mathrm{H}_{2} \mathrm{SO}_{4} \\
(\mathrm{ml})\end{array}$ & $\begin{array}{l}\text { Mass } \\
\text { of } \\
\mathrm{NaOH} \\
(\mathrm{g})\end{array}$ & $\begin{array}{l}\text { Mass } \\
\text { of } \\
\text { Yeas } \\
t(g)\end{array}$ & $\begin{array}{l}\text { Volu } \\
\text { me of } \\
\mathrm{H}_{2} \mathrm{O} \\
\text { used } \\
(\mathrm{ml})\end{array}$ & $\begin{array}{l}\mathrm{Ti} \\
\mathrm{me} \\
(\mathrm{mi} \\
\mathrm{n})\end{array}$ & $\begin{array}{l}\text { Volume } \\
\text { of } \\
\text { Ethanol } \\
\text { Obtained } \\
\text { (litre) }\end{array}$ \\
\hline 1 & 1500 & 40.78 & 60 & 310 & 1500 & 180 & 0.59 \\
\hline 2 & 1500 & 40.78 & 60 & 310 & 1500 & 180 & 0.58 \\
\hline 3 & 1500 & 40.78 & 60 & 310 & 1500 & 180 & 0.60 \\
\hline 4 & 1500 & 40.78 & 60 & 310 & 1500 & 180 & 0.61 \\
\hline 5 & 1500 & 40.78 & 60 & 310 & 1500 & 180 & 0.58 \\
\hline Total & & & & & & & 2.96 \\
\hline Average & & & & & & & 0.59 \\
\hline 6 & 1500 & 40.78 & 60 & 310 & 1500 & 200 & 0.60 \\
\hline 7 & 1500 & 40.78 & 60 & 310 & 1500 & 200 & 0.62 \\
\hline 8 & 1500 & 40.78 & 60 & 310 & 1500 & 200 & 0.61 \\
\hline 9 & 1500 & 40.78 & 60 & 310 & 1500 & 200 & 0.60 \\
\hline 10 & 1500 & 40.78 & 60 & 310 & 1500 & 200 & 0.63 \\
\hline Total & & & & & & & 3.06 \\
\hline Average & & & & & & & 0.61 \\
\hline
\end{tabular}

It was shown also in table 5 high average volume of alcoholic extraction at 200 minutes (0.81litres) to that of 180 minutes (0.79litres). The quantity of alcoholic extracted depends on quantity of starch used. The higher the quantity of cassava starch will lead to higher durations of extraction. 
Table 5: The volume of Ethanol Extracted at 2000g quantity of Starch

\begin{tabular}{|c|c|c|c|c|c|c|c|}
\hline $\mathrm{S} / \mathrm{N}$ & $\begin{array}{l}\text { Mass } \\
\text { of } \\
\text { Starch } \\
(\mathrm{g})\end{array}$ & $\begin{array}{l}\text { Volu } \\
\text { me of } \\
\mathrm{H}_{2} \mathrm{SO}_{4} \\
(\mathrm{ml})\end{array}$ & $\begin{array}{l}\begin{array}{l}\text { Mass } \\
\text { of }\end{array} \\
\mathrm{NaOH}( \\
\mathrm{g})\end{array}$ & $\begin{array}{l}\text { Mass } \\
\text { of } \\
\text { Yeast } \\
(\mathrm{g})\end{array}$ & $\begin{array}{l}\text { Volu } \\
\text { me of } \\
\mathrm{H}_{2} \mathrm{O} \\
\text { used } \\
\text { (ml) }\end{array}$ & $\begin{array}{l}\mathrm{Ti} \\
\mathrm{me} \\
(\mathrm{mi} \\
\mathrm{n})\end{array}$ & $\begin{array}{l}\text { Volume } \\
\text { of } \\
\text { Ethanol } \\
\text { Obtained } \\
\text { (litre) }\end{array}$ \\
\hline 1 & 2000 & 55.20 & 80 & 430 & 2000 & 180 & 0.77 \\
\hline 2 & 2000 & 55.20 & 80 & 430 & 2000 & 180 & 0.79 \\
\hline 3 & 2000 & 55.20 & 80 & 430 & 2000 & 180 & 0.80 \\
\hline 4 & 2000 & 55.20 & 80 & 430 & 2000 & 180 & 0.82 \\
\hline 5 & 2000 & 55.20 & 80 & 430 & 2000 & 180 & 0.78 \\
\hline Total & & & & & & & 3.96 \\
\hline $\begin{array}{l}\text { Avera } \\
\text { ge }\end{array}$ & & & & & & & 0.79 \\
\hline 6 & 2000 & 55.20 & 80 & 430 & 2000 & 200 & 0.81 \\
\hline 7 & 2000 & 55.20 & 80 & 430 & 2000 & 200 & 0.83 \\
\hline 8 & 2000 & 55.20 & 80 & 430 & 2000 & 200 & 0.79 \\
\hline 9 & 2000 & 55.20 & 80 & 430 & 2000 & 200 & 0.81 \\
\hline 10 & 2000 & 55.20 & 80 & 430 & 2000 & 200 & 0.82 \\
\hline Total & & & & & & & 4.06 \\
\hline $\begin{array}{l}\text { Avera } \\
\text { ge }\end{array}$ & & & & & & & 0.81 \\
\hline
\end{tabular}

The analysis of variance (ANOVA) of the results obtained was shown in table 6 . At $5 \%$ probability level, the results signify that the feed rate and time are important parameters that affect the volume of ethanol extracted with the machine. It means that these two parameters affect the performance of the extractor significantly.

Table 6: Analysis of variance

Variate: VOL

\begin{tabular}{llllll}
\hline $\begin{array}{l}\text { Source of } \\
\text { Variation }\end{array}$ & d.f. & s.s. & m.s.. & v.r. & F.p.r \\
\hline FED & 3 & 1.9965900 & 0.6655300 & 2974.44 & $<.001$ \\
TME & 1 & 0.0032400 & 0.0032400 & 14.48 & $<.001$ \\
FED.TME & 3 & 0.0013200 & 0.0004400 & 1.97 & 0.139 \\
Residual & 32 & 0.0071600 & 0.0002237 & & \\
Total & 39 & 2.0083100 & & & \\
\hline
\end{tabular}

VOL $=$ VOLUME

FED $=$ FEED RATE

$\mathrm{TME}=\mathrm{TIME}$

The additives for the extraction, which include volume of tetrahydrosulphate(vi) acid $\left(\mathrm{H}_{2} \mathrm{SO}_{4}\right)$, mass of sodium hydroxide $(\mathrm{NaOH})$, mass of yeast and volume of water increases as the quantity of cassava starch used increases.

\section{CONCLUSIONS AND RECOMMENDATION}

The performance test showed that cassava is another feed stock for producing ethanol at a reasonable time and without drudgery. Also, flammability test was carried out by lighting a stick of matches after which small quantity of the distillate ethanol was poured on the floor and the lighted stick was brought near the poured mixture and it was able to catch fire, which showed that the water content in the mixture was very small. Therefore, the ethanol extracted can be used to power internal combustion engine. The test showed that high quality hydrous ethanol was obtained at $75 \%$ purity, but as the ethanol was put to further distillation, the purity increases to $95 \%$. This means that higher time of distillation will lead to higher quality and low quantity of ethanol. The water jacket of the extractor should be made lower than the steam boiler and should be constructed with glass in order to increase the rate of condensation because glass conducts less heat than stainless steel. Malt should be used instead of acid during the breaking down of the starch to simple sugar.

\section{REFERENCES}

[1] O. Adeoti, Water Impact of E5 Production from Cassava Root in Nigeria. Proceedings of $4^{\text {th }}$ Engineering Forum, School of Engineering, the Federal polytechnic, Ado-Ekiti, Nigeria, 22 $2^{\text {nd }}$ August 2008

[2] C.T. Ajayi, Production and Evaluation of Custard from corn starch and Cassava starch. HND Project Department of Food Technology. The Federal Polytechnic, Ado-Ekiti, Nigeria. pp3940, 2003

[3] A.D. Akeredolu, Production and Evaluation of Ethanol and Vinegar from Pawpaw Fruit. HND Project Department of Food Technology. The Federal Polytechnic, Ado-Ekiti, Nigeria, pp1-2, 2002.

[4] M.O.Akinola, Agricultural Mechanization and the Nigerian Reforms: cassava production as a case study. Proceedings of $3^{\text {rd }}$ Engineering Forum, School of Engineering, Federal Polytechnic, Ado Ekiti, Nigeria, 14 ${ }^{\text {th }}$ August, 2007.

[5] B.O.Awe, Production and Evaluation of Ethanol from Cassava, HND Project Department of Food Technology, The Federal Polytechnic, Ado-Ekiti, Nigeria, pp7-8, 2000.

[6] IITA, Integrated Cassava Project: Ethanol from cassava (online) htty:/ /www.cassavabiz.org/ postharvest/ethanol 101.htm, 7 July, 2015.

[7] D.E.Kay, TPI Crop and Product Digest, 2.Root crops. Tropical Production .London. pp342-343, 1999.

[8] D.Kelvin, W.Donald, J.R.Precott, M. Lansing, O.Harley, and S.John, Microbiology. New York: Mc Graw- Hill (online). http // highered-mcgrawhill.com/ sites/0072556781/information centre view pp98, 25 July, 2015.

[9] O.Kitani, Energy and Biomass Engineering, CIGR Hand Book of Agricultural Engineering ol. V, pp106, 1999.

[10] A.R.Myers, L.Richard, P.K.Myers, and L.Rusty, The 100 most important chemical compounds: a reference guide. Westport, Greenwood Press. pp122, 2007.

[11] D.C.Nwosu, and S.O.Egbuna, Organic Chemistry (2 ${ }^{\text {nd }}$ Ediction). Department of Chemical Engineering, Enugu State University of Science and Technology, Enugu. Folsun Technology Nigeria. pp122, 2015.

[12] A.Ralph, and M.O.Burnsi, Fundamental of Chemistry ( $3^{\text {rd }}$ edition). New York, pp605-606, 1992.

[13] A.L.Osagie, Nutritional Quality of Plant Foods. M.Eng Thesis, Department of Biochemistry, University of Benin city, Nigeria pp 190, 1998.

[14] Wikipedia, Net fuel energy balance [online], Http/ / www.ethanolrfa.org/ pubs.shtml, 14 May, 2015.

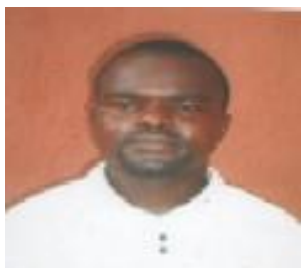

Ugwu Kenneth Chikwado from Aku, Igbo Etiti Local Government of Enugu State, Nigeria; B. Eng and M. Eng (2004 and 2010 respectively), Federal University of Technology, Minna, Nigeria; PhD student, Department of Agricultural and Bioresource Engineering, University of Nigeria Nsukka, Nigeria; MNSE, COREN Registered, Lecturer II in Department of Agricultural and Bioresource Engineering, Enugu State University of Science and Technology, Enugu, Nigeria; chikwadok@yahoo.com.

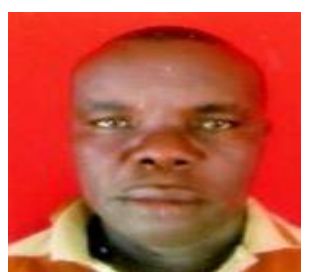

Omoruyi Anthony from Urhonigbe town in Orhionmwon Local Government of Edo State Nigeria. B. Eng and PGD Agricultural and Bioresource Engineering, Enugu State University of Science and Technology, Enugu, Nigeria; M. Eng Student in Agricultural and Bioresource Engineering, Enugu State University of Science of Technology, Enugu, Nigeria; Currently a Lecturer III in Agricultural Mechanization, Edo State College of Agriculture, Iguoriakhi, Nigeria. tonruyi@yahoo.com. 
